\title{
Post Choice Satisfaction among Nigerian Students Studying in Malaysian Universities: A Pilot Study
}

Aliyu Bukola Biodun*, Abdul Kadir Haji Din ${ }^{1 *} \&$ Aliyu Olayemi Abdullateef ${ }^{2 *}$

*MSc Research Candidate

College of Law, Government and International Studies, University Utara Malaysia

E-mail: bukyaliyu@yahoo.com

$1_{* \mathrm{PhD} \text { Professor }}$

College of Law, Government and International Studies,

University Utara Malaysia

E-mail: kadirdin@uum.edu.my

${ }^{2}$ *PhD Assistant Professor

College of Business, University Utara Malaysia

E-mail: aliyu@uum.edu.my

Received: February 6, 2012 Accepted: May 27, 2012 Published: June 15, 2012

doi:10.5296/ije.v4i2.1960 URL: http://dx.doi.org/10.5296/ije.v4i2.1960 


\section{Macrothink}

\section{Abstract}

Purpose - This research aims at developing a conceptual framework and valid prepositions of the impacts of Nigerian students' perceived expectation on perceived quality and satisfaction with Malaysian higher institutions. The result of this study will be used for a further research that will empirically establish the actual reason for the increasing influx of Nigerian students in Malaysia and how the stakeholders can best explore the inherent opportunities.

Design/methodology/approach - The researchers primarily use qualitative approach and pilot study that involves detail literature reviews of academic literatures and industry reports on perceived expectation, perceived quality and student satisfaction.

Findings - The extant literatures suggest that there exist positive relationship between perceived expectation, perceived quality and student satisfaction. The reliabilities of the proposed measurement instruments indicate valid internal consistency.

Research limitations/implications - Given that this paper is based on qualitative approach, there is need to embark on empirical data gathering to validate the conceptual model.

Practical implications - Evidence from existing literatures have established that for higher institutions of learning to achieve operational efficiency in their perceived service quality and student satisfaction, managements of higher institutions need to integrate high quality lecturers, reasonable cost of education, social orientation programs, modern facilities etc into their operations' measurement practices.

Originality/value - This research extensively review existing literatures on student satisfaction and measurements, specifically how it impact education industry. It primarily avails both the academic and higher institution's management the benefits that are inherent in measuring the impact of perceived expectation on perceived quality and student satisfaction. The research finally proposed a model for future empirical testing.

Keywords: student satisfaction, perceived expectation, perceived service quality

Paper type - Pilot study 


\section{Introduction}

For this study, issues of customer satisfaction and international education are the two major themes of investigation. However, given that this study primarily focus on CS/D, significant constructs of interest such as perceived expectation (pre-purchase) and perceived quality (post-purchase) are extensively reviewed to give credence to the established relationships between the research questions, theoretical framework and related theories (Arambewela and Hall, 2009). The themes in the theoretical framework of this study are directly related to the research questions which seek to establish the satisfactions of Nigerian students despite the negative image of Nigerians in Malaysia. Most important is how Nigerian students perceive their expectation and actual experience with the Malaysian higher institutions in terms of the services that are provided by these institutions of learning. In this context, measuring the impact of the perceived expectation and perceived service quality of Nigerian students on satisfaction and dissatisfaction becomes extremely important. The provided literature review on customer satisfaction theory and cognitive dissonance theory are both justified based on the insight that they provided in examining Nigerian students' disconfirmation of expectations as critically examined in this thesis.

\section{Choice of international study destinations}

Notably, there are different research approaches that are common within the academic literatures that relate to making choice of a study destination by any prospective international students. Available literatures have shown that a major approach is by looking at those macro-economic variables (standard of living, social orientation, economic factors, safety, modern technology etc) that may influence students' outflow from one country to the other in search of better higher education system (Arambewela and Hall, 2009).

A detailed review of available literatures indicates that none of those researchers that have examined the impact of macro-economic factors on international student satisfaction have establish the difference between perceived expectation (pre-purchase) and perceived quality (post-purchase) as conceptualized by Fornell et al. (1996) in American customer satisfaction index. Hence, a major contribution of this study is to establish the differences between pre-purchase and post-purchase intentions of Nigerian students and its overall impact on satisfactions with the educational and non-educational services in Malaysia.

\section{Research Model and Hypotheses}

Evidence from existing literature has show that tourism researchers have traditionally focused on issues that relate to the demand sides of the tourist motivations and few behavioral patterns mainly to discover the reasons that made tourists visit a particular destination (Chen and Tsai, 2007; Alcaniz et al., 2005). This conceptual framework will look into the relationships that exist among three major constructs of American customer satisfaction index (ACSI, 1996) i.e. perceived expectation, perceived quality and satisfaction. However, it has been proven by some researcher such as Chen and Tsai (2007), Fornell et al., (1996) and Turel and Serenko, (2006), that there are interrelation among perceived expectation, perceived quality and satisfaction. Notably, these interrelationships have been conceptualized in the research framework as shown below to determine the outcomes of Nigerian students' 
expectation on Malaysian higher institutions quality and satisfaction. Below is the conceptual framework of this current study:

\section{Conceptual Framework of the research study}

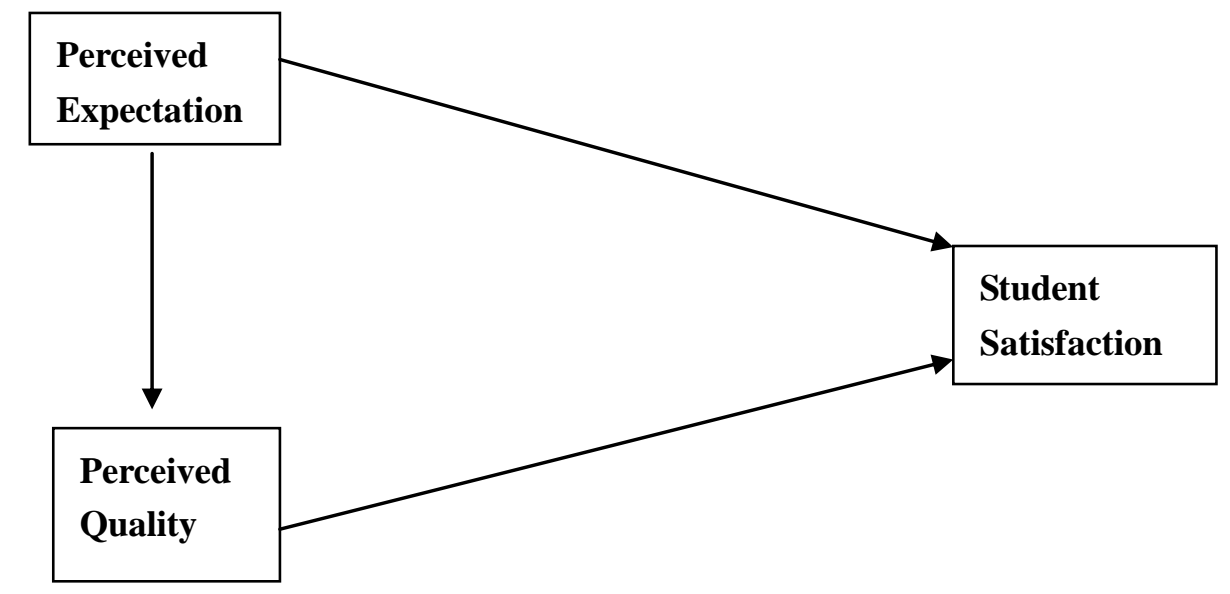

Independent Variable

Mediating Variable

Dependent

\begin{tabular}{|l|l|l|l|}
\hline $\begin{array}{l}\text { Perceived } \\
\text { expectation }\end{array}$ & $\begin{array}{l}\text { Perceived } \\
\text { quality }\end{array}$ & $\begin{array}{l}\text { Student } \\
\text { satisfaction. }\end{array}$ \\
\cline { 3 - 4 }
\end{tabular}

In education sector, students' satisfaction is crucial for higher institution success, the sector make destination marketing very important because it influences the choice of destination students will make, and the decision to return or recommend to others (Arambewela and Hall, 2009). Furthermore, customer satisfaction is defined as a cumulative evaluation of a customer's purchase and consumption experience to date (Turel and Serenko, 2006). Satisfaction is the extent of all contentment felt by the visitor, that come from the trip experience that fulfill the tourists desires, expectations and needs relating to the trip (Chen and Tsai, 2006). Satisfaction is the result from an emotional judgment of the tourists, satisfaction from the service encounter by the tourists, and specific moment in time. Moreover, tourist satisfaction was also defined as the degree to which tourist requirements are satisfied in a given relation between the producer and the consumers. In one of Chen's study in (2008), he mentions that satisfaction is affective answer to a perceived discrepancy that exists between prior expectation and perceived performance after consumption. For students to have overall satisfaction, their overall subjective post-consumption evaluation entails all encounters and experiences students or customers have with a particular organization or destination (Chen, 2008).

As evident in recent years there have been a number of empirical studies on student's expectations and perceptions on specific service quality attributes (Arambewela and Hall, 2009). However, very little research has investigated the impact of international students' 
expectations of the destination country on service quality and satisfaction (Hanaysha et al., 2011)). In the tourism sector, it is very important to research on what the students will likely expect on their chosen destination for higher education. Although there are different students with different cultural background and also they have different ways of reacting or weighting their expectation so tourism marketing department need to research to know how to satisfy student expectation. According to Arambewela and Hall (2009), they investigate student expectation on quality of higher institutions and the influence the individual background differences will have on expectation, so it is normal for a student with different thought of perceiving things to have different expectations toward service encounters on the destination.

One of the most widely adopted frameworks in understanding customer perception is Fornell et al., (1996), a model that was adopted worldwide to solve customer perceived expectation. However, this study has adopted fornell et al (1996) conceptual framework of customer satisfaction given its global acceptance in studying the impact of perceived expectation of Nigerian students on service quality and satisfaction of Malaysian higher institutions. Few existing literature have suggested that consumer satisfaction is a function of both expectations related to certain important attributes and judgments of attribute performance (Sumaedi et al., 2011). It must be known that satisfaction is the comparison of the product expectation and actual performance of the product. In the tourism sector industry, tourist satisfaction is a priority and this is based on the goodness that fit the expectation about a destination, the perceived evaluative experience in the destination that is the favorable experience, tourists feeling on the destination will contribute to this evaluation. In order to react to the complex nature of mental ways of satisfaction evaluation and the theories of measuring satisfaction, the evaluation of tourist satisfaction should look in different dimensions and in integrated approaches, because tourists have different motivation when visiting destinations and they also have different satisfaction levels. There are many studies that try to examine the theoretical and methodological contexts of tourist satisfaction and most of the studies suggest that there is need for a deeper investigation to better understand the issue of tourist satisfaction.

As mentioned above few recent studies have discovered that customers from different places formed different perceptions of perceived quality, because of the differences in expectations or the way they attached different weighting to different service quality they encounter. For example, ASCI (2001), and Nelson (2009), investigated how tourists in the Asian and Western countries have evaluated service encounters and found that Asian and Western services gave significantly different ratings on restaurant employee behavior. These findings show that customers from different cultures assigned different importance to weightings; hence Hanaysha et al (2011) used SERVQUAL to measure student perceived quality of higher institutions. Within the tourism industry, a unique quality model that has been mostly adopted is the American satisfaction index as conceptualized and empirically validated by Fornell et al., (1996). Importantly, this model comprises of perceived expectation as the independent variable, where perceived quality, perceived value, customer satisfaction, customer complaint are the mediating variables and customer loyalty has the dependent (Fornell et al., 1996). Based on ASCI and many more evidences, this study hypothesizes the 


\section{Macrothink}

International Journal of Education

ISSN 1948-5476

2012, Vol. 4, No. 2

following relationships:

H1: Nigerian students' perceived expectation is positively related to their perceived quality

H2: Nigerian students' perceived expectation is positively related to their satisfaction

H3: Nigerian students' perceived quality is positively related to their satisfaction

H4: Nigerian students' perceived quality positively mediate the relationship between their perceived expectation and satisfaction

\section{Operationalization of Perceived Service Quality}

Notable among foreign student satisfaction literatures that have empirically established the perceived service quality on students' satisfaction is Arambewela and Hall, (2009) and Sumaedi et al (2011). For this current study, below are some important sources through which the measurement instruments for this current study were developed:

Table 1: Operationalization of Perceived Expectation Construct

\begin{tabular}{|c|c|c|c|}
\hline \multirow{2}{*}{$\begin{array}{l}\text { Dimensions } \\
\text { Perceived } \\
\text { Expectation }\end{array}$} & & Items & Source \\
\hline & $\begin{array}{l}10 \\
11\end{array}$ & $\begin{array}{l}\text { I expect Malaysian higher institutions to provide high } \\
\text { standard of teaching with quality lecturers that } \\
\text { provides valuable feedbacks } \\
\text { I expect Malaysian higher institutions to provide } \\
\text { reasonable cost of education } \\
\text { I expect Malaysian higher institutions to put in place } \\
\text { avenue for close working relationships among all } \\
\text { students } \\
\text { I expect Malaysian higher institutions to provide } \\
\text { counseling services and other International orientation } \\
\text { programs } \\
\text { I expect Malaysia to have a moderate cost of living } \\
\text { I expect Malaysia to provide opportunities for casual } \\
\text { jobs and migration } \\
\text { I expect Malaysian government to provide required } \\
\text { security and safety } \\
\text { I expect Malaysians to have moderate life-style that } \\
\text { will encourage racial tolerance } \\
\text { I expect Malaysian higher institutions to be of good } \\
\text { image at international level } \\
\text { I expect Malaysian higher institutions to possess } \\
\text { required modern facilities } \\
\text { I expect Malaysian higher institutions to provide good } \\
\text { accommodation with reasonable cost }\end{array}$ & $\begin{array}{l}\text { Hanaysha et } \\
\text { al, (2011); } \\
\text { Sumaedi et al } \\
\text { (2011); } \\
\text { Arambewela } \\
\text { and Hall, } \\
\text { (2009); } \\
\text { Fornell et al., } \\
\text { (1996) }\end{array}$ \\
\hline
\end{tabular}




\section{Macrothink}

International Journal of Education

ISSN 1948-5476

2012, Vol. 4, No. 2

Table 2: Operationalization of Perceived Quality Construct

\begin{tabular}{|c|c|c|c|}
\hline Dimensions & & Items & Source \\
\hline $\begin{array}{l}\text { Perceived } \\
\text { Service } \\
\text { Quality }\end{array}$ & $\begin{array}{l}5 \\
6 \\
7 \\
8 \\
9 \\
10 \\
11\end{array}$ & $\begin{array}{l}\text { Malaysian higher institutions provides high standard of } \\
\text { teaching with quality lecturers that provides valuable } \\
\text { feedbacks } \\
\text { Malaysian higher institutions provides reasonable cost } \\
\text { of education } \\
\text { Malaysian higher institutions puts in place avenue for } \\
\text { close working relationships among all students } \\
\text { Malaysian higher institutions provides counseling } \\
\text { services and other International orientation programs } \\
\text { Malaysia has a moderate cost of living } \\
\text { Malaysia provides opportunities for casual jobs and } \\
\text { migration } \\
\text { Malaysian government provides required security and } \\
\text { safety } \\
\text { Malaysians have moderate life-style that encourage } \\
\text { racial tolerance } \\
\text { Malaysian higher institutions have good image at } \\
\text { international level } \\
\text { Malaysian higher institutions possess modern facilities } \\
\text { Malaysian higher institutions provides good } \\
\text { accommodation with reasonable cost }\end{array}$ & $\begin{array}{l}\text { Hanaysha et } \\
\text { al, (2011); } \\
\text { Sumaedi et al } \\
\text { (2011); } \\
\text { Arambewela } \\
\text { and Hall, } \\
\text { (2009); } \\
\text { Fornell et al., } \\
\text { (1996) }\end{array}$ \\
\hline
\end{tabular}

Table 3: Operationalization of Student Satisfaction Construct

\begin{tabular}{|c|c|c|c|}
\hline Dimensions & & Items & Source \\
\hline $\begin{array}{l}\text { Student } \\
\text { Satisfaction }\end{array}$ & 1 & $\begin{array}{l}\text { I am satisfied with the quality of education that is provided by } \\
\text { Malaysian higher institutions } \\
\text { I am satisfied with the social orientation programs that are } \\
\text { provided by Malaysian higher institutions } \\
\text { I am satisfied with my economic considerations for choosing } \\
\text { Malaysia as my destination of study } \\
\text { I am satisfied with available security and level of safety in } \\
\text { Malaysia } \\
\text { I am satisfied with the image and prestige of Malaysian } \\
\text { higher institutions at home and abroad } \\
\text { I am satisfied with the available facilities in Malaysian higher } \\
\text { institutions } \\
\text { I am satisfied with the accommodations that are provided by } \\
\text { Malaysian higher institutions }\end{array}$ & $\begin{array}{l}\text { Hanaysha et al, } \\
\text { (2011); Sumaedi } \\
\text { et al (2011); } \\
\text { Arambewela and } \\
\text { Hall, (2009); } \\
\text { Fornell et al., } \\
\text { (1996) }\end{array}$ \\
\hline
\end{tabular}




\section{Pilot Study}

To establish the reliability of the selected measurement instruments, this study has conducted a pilot study with the use of convenience sample of 40 Nigerian postgraduate students studying in Malaysian higher institutions. As evident in existing literatures, this study has made used of content reliability to determine if the hypothesized items are actually measuring their constructs (Hair et al., 2010). To do this, the researchers conducted a critical assessment of all the items' reliability to primarily examine loadings or the correlations of their measures with the construct upon which they were hypothesized. Theoretically, a cronbach's alpha of a loading 0.70 has been suggested by Nunnally and Bernstein (1994) as the cut off criterion, however there are some other authors that have suggested a less conservative benchmark of 0.60. Their arguments are based on the fact that the internal consistency measures of a cronbach's alpha primarily represent the extents that the hypothesized items actually converge to measure the variable of interest. Below is Table 4 that list out the outcomes of the cronbach's alpha in the pilot study:

Table 4: Reliability Cronbach Alpha (Pilot Study)

\begin{tabular}{ll}
\hline Construct & Cronbach Alpha \\
\cline { 2 - 2 } & Pilot Study $\mathbf{n = 4 0}$ \\
\hline 1. Perceived Expectation & 0.780 \\
2. Perceived Service Quality & 0.785 \\
3. Student Satisfaction & 0.731 \\
\hline
\end{tabular}

The above results have shown that the selected measurement items truly represent the hypothesized constructs in the research framework.

\section{Conclusion}

The extant literatures on international students' satisfactions within the tourism industry have been extensively argued as depending on seven dimensions under disconfirmation of perceived expectations and perceived quality paradigm namely (a) economic considerations (b) standard of education and facility (c) access to modern technology (d) social orientation (e) safety (f) image and prestige (g) accommodation. Notably, all the aforementioned themes were argued as having their individual and collective relevance on students' actual satisfaction or dissatisfaction. However, given the current influx of Nigerian students in Malaysia, this study has conceptualized a framework and pilot study that will help in examining the post choice satisfaction of Nigerian students with Malaysian higher institutions of learning. To establish the theoretical linkages between the above measurement instruments of international student satisfaction, this study has reviewed relevant literatures and conducted pilot test on students' satisfaction constructs.

Notable among the significance of this paper is its contribution to theory with developed conceptual framework that will assist in empirically establishing the impacts of students' expectations on perceived quality and satisfactions. It has also explained the theoretical 
linkages that exist between students' perceived expectation, students' perceived quality and satisfaction with higher institutions of learning.

To the higher institutions management, this research has further established the importance of students' perceived expectation as a strategic tool through which education sector can use in satisfying the international students. The researchers believe that inputs from the impacts of perceived expectation within the education industry will serve as a strong basis for the higher institutions management to know more about their operational processes. Findings from the mediating impact of perceived quality could be used by higher institutions management in determining alternative solutions to their observed lapses within the education industry.

\section{References}

Alcaniz, E. B., Isabel, S. G., \& Blas, S.S. (2005). Residents, destination image, evaluation of stay, post-purchase behavior. Journal vacation marketing, 111(4), 291- 302. http://dx.doi.org/10.1177/1356766705056626

Arambewela, R \& Hall, J (2009). An empirical model of international student satisfaction. Asia Pacific Journal of Marketing and Logistics, 21(4), pp. 555-569. http://dx.doi.org/10.1108/13555850910997599

Chang, C.F. (2008). Attribution Tourists' Satisfaction Judgments: An Investigation of Emotion, Equity, and Attribution. Journal of Hospitality \& Tourism Research, 32(1), 108-134. http://dx.doi.org/10.1177/1096348007309571

Charles, A. (2010). Managing Tourism in Nigeria: The Security Option; Management Science and Engineering, 4(1), 14-25.

Chen, C., \& Tsai, D. (2007). How destination affect tourist behavior. Tourist management, 28(1), 1115-1122.

Fakeye, P. C., \& John, L. C (1991). Image differences between prospective, first time, repeat visitor to the lower Roi ground valley. Journal of travel research, 30(2), 10-16. http://dx.doi.org/10.1177/004728759103000202

Fang, M., Yodmanee, T.. \& Muzaffer, U. (2008). Measuring tourist satisfaction by attribute and motivation. Journal of vacational Marketing, 14(1), 41-56.

Fornell, C., Johnson, M. D., Anderson, E. W., \& Cha, J. B. (1996). The American Customer Satisfaction Index. Journal of marketing, 60, 7-18. http://dx.doi.org/10.2307/1251898

Hair, J. F., Jr., Black, W. C., Babin, B. J., Andersen, R. E., \& Tatham, R. L. (2010). Mutilvariate data analysis (7th ed.). Upper Saddle River, NJ: Pearson Prentice Hall.

Hanaysha, J., Abdullah, H., \& Warokka, A. (2011). Service Quality and Students' Satisfaction at Higher Learning Institutions: The Competing Dimensions of Malaysian Universities' Competitiveness. Journal of Southeast Asian Research, volume 1.

Immigration Department of Malaysia, (2009). International Tourist Arrivals. Retrieved from: http://www.imi.gov.my/ 
Jani, R., \& Zabairin, Y Z. (2010). International Students' Views of Malaysian Higher Education, Internalisation and marketing of higher education Malaysian,June 2010 putrajaya.

Karim, M. S., \& Bee-lia, C. (2009). Malaysia as a culinary tourism destination: international tourist. Journal of tourism, hospitality and culinary art.

Ministry of Tourism Malaysia (2010). Retrieved on the 7th of October, 2010 fromwww.tourism.gov.my/corporate/research.asp?page=facts_figures

Nelson, K. T., \& John, AP. (2007). Perceptions of Relational Quality Service Attributes, Journal of Travel Research, 45(2), pp. 355-363.

Nunnally, J. C., \& Bernstein, I. H. (1994). Psychometric theory (3rd ed.). New York: McGraw-Hill.

Nworah, U. (2006). Critical Perspectives on The Heart Of Africa Image Project Rebranding Nigerian, Working Paper.

Sirat, M., Tan, C., \& Subramaniam, T. (2010). Review of the roles of Higher Education in City Region Development (Penang); Working Paper.

Sirgy, M. J., Kruger, P. S., Lee, D. J., \& Yu, G. B. (2010). How Does a Travel Trip Affect Tourists' Life Satisfaction? Journal of Travel Research 20(10) 1-15.

Sumaedi, S., Bakti, G., \& Metasari, N. (2011). The Effect of Students' Perceived Service Quality and Perceived Price on Student Satisfaction: Management Science and Engineering, 5(1), 88-97

Taylor S.A., \& Baker T.L. (1994). An assessment of the relationship between service quality and customer satisfaction in the formation of consumers' purchase intentions. Journal of Retailing, 70(2).

Zeithaml, A. V., Parasuraman A., \& Berry L. L. (1985). Problems and Strategies in Services Marketing. Journal of Marketing, 49(2), 33-46. http://dx.doi.org/10.2307/1251563

Zeithaml, B., \& Parasuraman A. (1993). The Nature and Determinants of Customer Expectations of Service. Journal of the Academy of Marketing Science, 1-12. http://dx.doi.org/10.1177/0092070393211001

\section{Copyright Disclaimer}

Copyright reserved by the author(s).

This article is an open-access article distributed under the terms and conditions of the Creative Commons Attribution license (http://creativecommons.org/licenses/by/3.0/). 